\title{
Cotton stalk-derived hydrothermal carbon for methylene blue dye removal: investigation of the raw material plant tissues
}

\author{
Libo Zhang ${ }^{1 *}$, Junyan Tan², Gangying Xing ${ }^{3}$, Xintong Dou ${ }^{3}$ and Xuqiang Guo ${ }^{1}$
}

\begin{abstract}
Conversion of the abundant agricultural residual cotton stalk (CS) into useful chemicals or functional materials could alleviate the fossil fuels caused energy shortages and environmental crises. Although some advances have been achieved, less attention has been paid to the plant tissues effect. In this study, the plant tissue of CS was changed by part degradation of some components (hemicelluloses and lignin, for example) with the aid of acid/base (or both). The pretreated CS was transformed into hydrochar by hydrothermal carbonization (HTC) method. Morphological and chemical compositions of CS hydrochar were analyzed by various techniques, including elemental analysis, Fourier transform infrared (FTIR), BET analysis, X-ray photoelectron spectroscopy (XPS) and X-ray diffraction (XRD). Methylene blue (MB) removal of prepared CS hydrochar was used to evaluate CS hydrochar pollutions adsorption capacity. Results reveal acid/base (or both) pretreatment is beneficial for CS raw material to prepare high-quality CS hydrochar. The effects of some parameters, such as initial $\mathrm{MB}$ concentration, temperature, $\mathrm{pH}$ value and recyclability on the adsorption of MB onto both acid and base-pretreated CS hydrochar $\left(\mathrm{CS}_{-} \mathrm{H}_{2} \mathrm{SO}_{4}+\mathrm{NaOH}-\mathrm{HTC}\right)$ were studied. The present work exhibits the importance of agricultural waste biomass material plant tissues on its derived materials, which will have a positive effect on the direct utilization of waste biomass.
\end{abstract}

Keywords: Cotton stalk, Acid/base pretreatment, Hydrothermal carbonization, Plant tissues, MB removal

\section{Background}

Over-reliance on fossil fuels has caused energy shortages and environmental crises. Looking for sustainable and inexpensive resources that can be obtained via environmentally friendly routes has never stopped. Conversion of non-food biomass into useful chemicals or functional materials is of great value on the sustainable development. Among those non-food biomass materials, cotton stalk (CS) is of large quantity. It is estimated that cotton production is about 25 million tons along with accounting for 50 million tons of biomass waste residues (Hamawand et al. 2016). Those residues mainly consist

\footnotetext{
*Correspondence: zhanglibo@cupk.edu.cn

1 State Key Laboratory of Heavy Oil Processing, College of Engineering, China University of Petroleum-Beijing at Karamay, Karamay 834000,

People's Republic of China

Full list of author information is available at the end of the article
}

of CS, which is produced after cotton harvesting (Song et al. 2020). Usual treatments of CS include discard and burning that result in biomass material waste, environmental pollution and global warming issues (Foong et al. 2020; Medronho and Lindman 2015). Instead, developing conversion technology of CS into fuels, chemicals or functional materials could realize the recycle of waste agriculture residues and reduce incineration-caused environmental pollution. Besides, the high-value of CS can bring economic benefits that return raise rural incomes and further promote the cotton planting industry (Hamawand et al. 2016).

Up to the present, great progress has been made for the conversion of CS into useful fuels, chemicals and functional materials. Such as solar pyrolysis for bio-fuel production (Xie et al. 2019), co-pyrolysis with sewage sludge to use as soil amendments (Wang et al. 2020), hydrolysis for hydrogen generation ( $\mathrm{Li}$ et al. 2020b), fermentation 
for ethanol production (Malik et al. 2020), synthesis of bio-degradable composites (Zhou et al. 2019), and carbonization for heavy metal ions removal (Hussain et al. 2020). Among those transformation technologies, carbonization has attracted tremendous attention for it is based on full component utilization of biomass raw materials, which is thus of economical efficiency (Liu et al. 2015; Ukanwa et al. 2019; Yang et al. 2019a). The produced carbonaceous material could be further used as a platform carbon material for the synthesis of various functional materials or directly used in some fields (as shown in Fig. 1) (Boostani et al. 2019; Liu et al. 2019; Vahdati-Khajeh et al. 2019; Yang et al. 2019b).

A common carbonization way for biomass materials is pyrolysis, including slow pyrolysis, fast pyrolysis, flash pyrolysis and pyrolytic gasification, which corresponds to biochar yield of $35-50 \%, 15-35 \%, 10-20 \%$ and $10-20 \%$ (wt\%), respectively (Bridgwater. 2012; Chu et al. 2013; Laird et al. 2009). Although pyrolysis could obtain a high carbon yield with rich functional groups, the temperature is high [generally $600-900{ }^{\circ} \mathrm{C}$ (Guo et al. 2020)]. As an alternative carbonization way, hydrothermal carbonation (HTC) has significant advantages such as low operating temperature $\left(180-250{ }^{\circ} \mathrm{C}\right)$ and the absence of a drying step, which reduces the energy consumption, and therefore, the operation cost is lower (Nizamuddin et al. 2017). To date, more attentions have been devoted to the regulations of hydrothermal conditions (temperature, retain time, atmosphere, catalysts, etc.), limited research focus

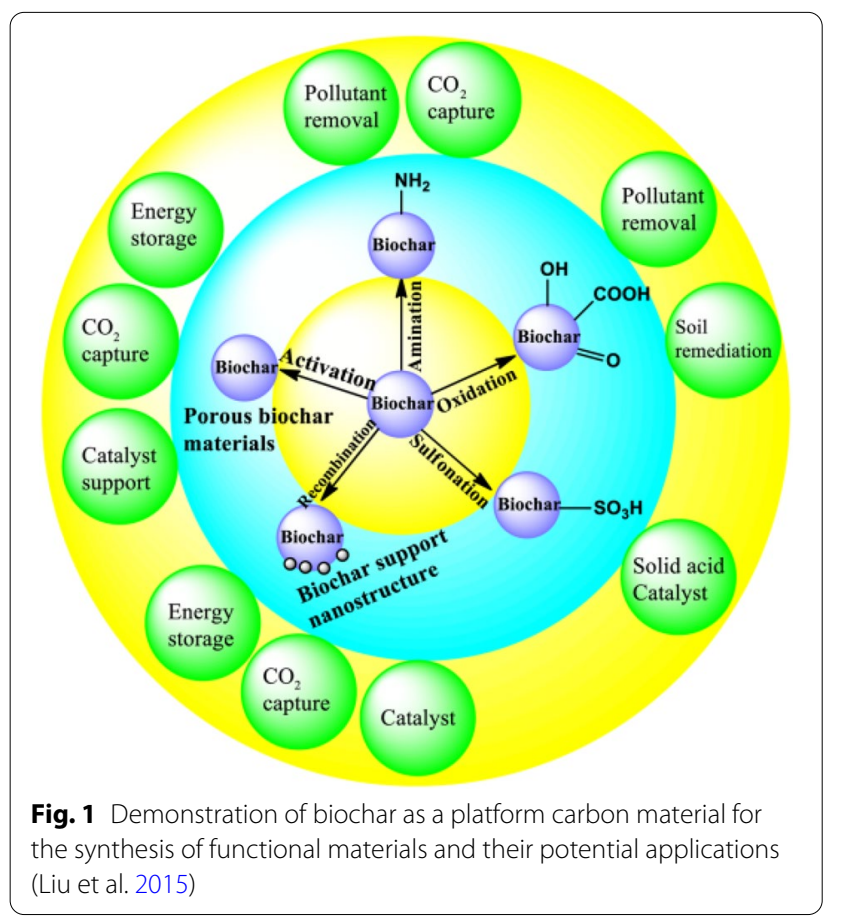

on the feedstock plant tissues of biomass resource (Nizamuddin et al. 2017). Lignocellulosic biomass feedstock is composed of three major constituents: cellulose, hemicelluloses and lignin, which form a structure of cellulose microfibrils incorporated in a matrix of hemicelluloses and lignin in the plant cell wall (Machado et al. 2016; Zhang et al. 2018b), while the interaction among these three major constituents during the HTC process is not absolutely comprehended.

Due to the above facts, simple mineral acid/base (or both acid and base) pretreatment were adopted to selectively remove part of the CS composition (hemicelluloses or lignin) in this study. The pretreated CS subsequently went through the HTC and activation processes. Finally, the acid/base (or both) pretreated CS hydrochar was used as adsorbent to evaluate their methylene blue (MB) dye adsorption capacity. The influence of simple acid/ base pretreatment was investigated to help understand the plant tissue effects on biomass derived materials from HTC process. Meanwhile, a simple acid/base pretreatment way was developed to prepare high MB adsorption capacity hydrochar from waste CS. The innovation of this work is to compare the major constituents and their effects during biomass HTC process for preparing high-quality hydrochar, which will provide some detailed understanding on biomass HTC process.

\section{Materials and methods}

Raw material and chemicals

CS was collected from local cotton fields (Karamay, Xinjiang, China) and pulverized into powder. Before the HTC process, the drying of grounded CS power was done for exact quantification. Sulfuric acid $\left(\mathrm{H}_{2} \mathrm{SO}_{4}\right)$, sodium hydroxide $(\mathrm{NaOH})$, potassium hydroxide $(\mathrm{KOH})$, ethanol and hydrochloric acid $(\mathrm{HCl})$ were supplied by the local supplier. Methylene blue $\left(\mathrm{MB}, \mathrm{C}_{16} \mathrm{H}_{18} \mathrm{ClN}_{3} \mathrm{~S}\right)$, glucose, cellulose, aniline and malachite green oxalate salt were purchased from Sigma-Aldrich. Deionized water (DI water, $18.25 \mathrm{M} \Omega \mathrm{cm}$ ) used in this study was prepared from a water purification system (Water Purifier, WPUP-UV-20, Sichuan Water Technology Development Co. Ltd., China).

All chemicals used in this study were of analytical grade and used without further purification.

\section{Acid/base (or both) pretreatment of CS}

CS powder was added into an $\mathrm{H}_{2} \mathrm{SO}_{4}$ (4\%, wt\%) or $\mathrm{NaOH}(5 \%$, wt\%) solution in water bath under vigorous stir at $95{ }^{\circ} \mathrm{C}$ for $4 \mathrm{~h}$ with a solid-liquid weight ration of 1:10. After pretreatment, the obtained solid was filtrated under reduced pressure and followed by drying in an oven at $105{ }^{\circ} \mathrm{C}$ till constant weight. Those solid were labeled as $\mathrm{CS}-\mathrm{H}_{2} \mathrm{SO}_{4}, \mathrm{CS}-\mathrm{NaOH}$ and $\mathrm{CS}-\mathrm{H}_{2} \mathrm{SO}_{4}+\mathrm{NaOH}$ 
(CS- $\mathrm{H}_{2} \mathrm{SO}_{4}+\mathrm{NaOH}$ indicates $\mathrm{CS}$ underwent consecutive $\mathrm{H}_{2} \mathrm{SO}_{4}$ and $\mathrm{NaOH}$ pretreatment). The effects of $\mathrm{H}_{2} \mathrm{SO}_{4}$ and $\mathrm{NaOH}$ on CS tissue structure are illustrated in Fig. 2 (Mukherjee et al. 2017; Yu et al. 2019; Zhang et al. 2019).

\section{Hydrothermal carbonization and activation}

A certain amount of $\mathrm{CS}-\mathrm{H}_{2} \mathrm{SO}_{4}, \mathrm{CS}-\mathrm{NaOH}$ and CS$\mathrm{H}_{2} \mathrm{SO}_{4}+\mathrm{NaOH}$ were mixed with DI water in a Teflonlined autoclave (Zhang et al. 2020b) (Nantong Bo Run Petroleum Science) with a solid/liquid weight ration of 1:10. The autoclave was heated to $220^{\circ} \mathrm{C}$ with a magnetic stir bar at $200 \mathrm{r} / \mathrm{min}$ and kept for $6 \mathrm{~h}$. After cooling down to room temperature with the aid of flow water, the solidstate samples were filtered and washed thoroughly with DI water until the filtrate was neutral. The neutral solidstate samples were dried in an oven at $105^{\circ} \mathrm{C}$ overnight.

Activation was performed in $\mathrm{KOH}$ solution at a weight ratio of 1:2 with excess amount of DI water, refluxed at $70{ }^{\circ} \mathrm{C}$ for $12 \mathrm{~h}$ (Salimi et al. 2017). The obtained power carbonaceous materials were washed thoroughly with DI water and dried in an oven. The samples were denoted as $\mathrm{CS}-\mathrm{H}_{2} \mathrm{SO}_{4}-\mathrm{HTC}$, CS- $\mathrm{NaOH}-\mathrm{HTC}$, $\mathrm{CS}-\mathrm{H}_{2} \mathrm{SO}_{4}+\mathrm{NaOH}-\mathrm{HTC}$.
Glucose, cellulose and crude CS also underwent the same HTC process and marked as Glucose-HTC, Cellulose-HTC and CS-HTC to further elucidate the role of CS plant tissue.

\section{CS-based HTC characterization}

Elemental analysis of sample for carbon, oxygen, hydrogen and nitrogen was performed with an elementary analyzer (Flash EA 1112). Fourier transform infrared (FTIR) spectroscopy (TENSOR-27, BRUKER, Germany) was used to monitor the samples' surface functional groups (range from 500 to $4000 \mathrm{~cm}^{-1}$ ). The porous texture was investigated with $\mathrm{N}_{2}$ adsorption-desorption isotherms at $-196{ }^{\circ} \mathrm{C}$ and fitted with BET equation (Micromeritic ASAP2460). The $\mathrm{O}^{1 \mathrm{~s}}$ and $\mathrm{C}^{1 \mathrm{~s}}$ spectrum of sample surface was conducted with $\mathrm{X}$-ray photoelectron spectroscopy (XPS, ESCALab250XI, VG), the spectrum decomposition from XPS was performed using the XPS PEAK 41 program with Lorentzian-Gaussian function after subtraction of a Shirley background. The crystal structure was identified by powder X-ray diffraction (XRD) (Bruker D8 Advance X-ray diffractometer, D/max 2500, Rigaku, Japan) with $\mathrm{Cu} K \alpha$ radiation $(\lambda=0.15406 \mathrm{~nm})$, the operating voltage and electric current were $40 \mathrm{KV}$ and $40 \mathrm{~mA}$.

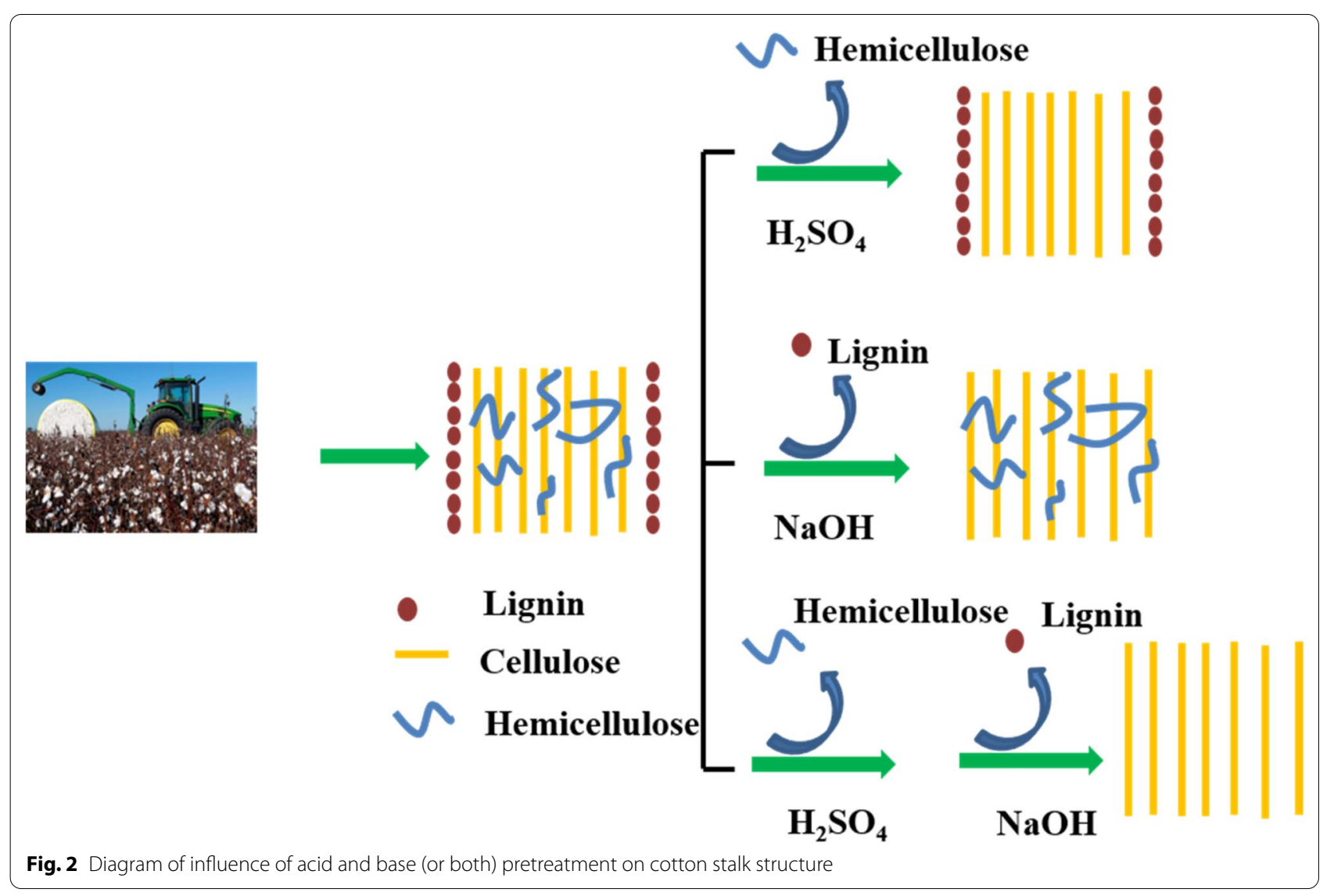




\section{Removal of MB}

Typically, a certain amount of prepared hydrochar was added into a sealed wide-mouth bottle with $75 \mathrm{~mL} \mathrm{MB}$ solution and then placed into a constant temperature shaker (CHA-AB, China) to investigate hydrochar types, initial $\mathrm{MB}$ concentration, temperature, $\mathrm{pH}$ value and reuse. A UV-VIS spectrophotometer (TU-1810, PERSEE, China) was used to determine MB concentration at different time intervals by withdrawing the aqueous samples for measurement at $664 \mathrm{~nm}$ wavelength with standard curve method (Vahdati-Khajeh et al. 2019) (see Additional file 1: Fig. S1). The uptake $Q_{t}(\mathrm{mg} / \mathrm{g})$ and $\mathrm{MB}$ removal rate $R$ (\%) were determined as:

$$
Q_{t}=\frac{\left(C_{0}-C_{t}\right) V}{W}, R(\%)=\frac{\left(C_{0}-C_{t}\right) 100}{C_{0}}
$$

where $C_{0}$ and $C_{t}(\mathrm{mg} / \mathrm{L})$ are the MB liquid-phase concentrations at the initial time and $t$ minutes, respectively. $V$ $(\mathrm{L})$ is $\mathrm{MB}$ solution volume, and $W(\mathrm{~g})$ is the adsorbent weight.

\section{Results and discussion}

\section{Characterization of samples}

The elemental compositions (wt\%) of CS hydrochars, glucose-derived HTC and cellulose-derived HTC were analyzed and atomic ratios of oxygen to carbon $(\mathrm{O} / \mathrm{C})$ and hydrogen to carbon $(\mathrm{H} / \mathrm{C})$ are calculated as shown in Table 1.

Besides, nitrogen element contents of $\mathrm{CS}-\mathrm{H}_{2} \mathrm{SO}_{4}$ $\mathrm{HTC}, \mathrm{CS}-\mathrm{NaOH}-\mathrm{HTC}, \mathrm{CS}-\mathrm{H}_{2} \mathrm{SO}_{4}+\mathrm{NaOH}-\mathrm{HTC}$ are obviously lower than CS-HTC (Table 1, entry 5), which means $\mathrm{H}_{2} \mathrm{SO}_{4} / \mathrm{NaOH}$ (or both) pretreatment could efficient remove nitrogen in CS biomass raw materials. And $\mathrm{NaOH}$ performs better nitrogen removal ability than $\mathrm{H}_{2} \mathrm{SO}_{4}$. Secondly, CS- $\mathrm{H}_{2} \mathrm{SO}_{4}-\mathrm{HTC}, \quad \mathrm{CS}-\mathrm{NaOH}-\mathrm{HTC}$ and $\mathrm{CS}-\mathrm{H}_{2} \mathrm{SO}_{4}+\mathrm{NaOH}-\mathrm{HTC}$ contain slightly higher $\mathrm{O} / \mathrm{C}$ ratio and lower $\mathrm{H} / \mathrm{C}$ ratio. It is generally accepted that decarboxylation, dehydration, condensation polymerization, hydrolysis, and aromatization are the main carbonaceous material generation pathway during HTC process (Khan et al. 2019; Sevilla and Fuertes 2009; Tu et al. 2019), dehydration action could reduce $\mathrm{H}$ content. Acid/base (or both) could selectivity remove hemicelluloses and lignin from CS that leads to high cellulose rich in pretreated CS. O-rich cellulose further enhances $\mathrm{O}$ content and $\mathrm{O} / \mathrm{C}$ atomic ratio in hydrochars ( $\mathrm{Li}$ et al. 2020a; Rusanen et al. 2019; Smith et al. 2016; Sun et al. 2020; Xu et al. 2019; Zhang et al. 2020a).

The information of BET surface area, pore volume (by $\mathrm{BJH}$ adsorption cumulative) and pore size (by BJH desorption date) of CS, glucose and cellulose-derived hydrochars is depicted in Fig. 3 and Table 2.

As shown in Fig. 3, the isotherm obtained for all samples could be classified as type I and type II isotherms (Román et al. 2012). The curves showed an upward trend near the relative pressure of approximately 0.9 , which indicates that the obtained hydrochars contain virtually no framework of confined pores (Adebisi et al. 2016). Information from Table 2 demonstrates the CS-derived

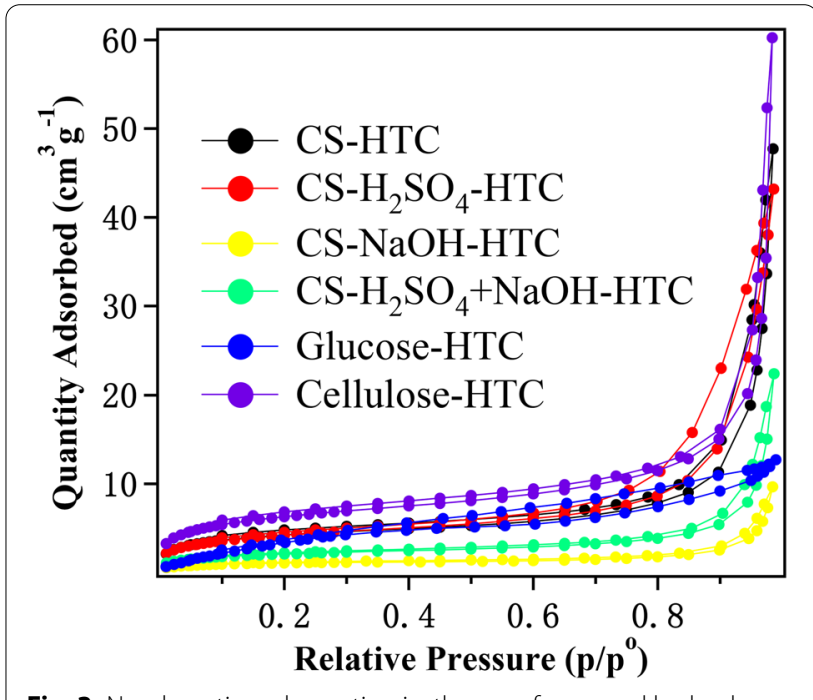

Fig. $3 \mathrm{~N}_{2}$ adsorption-desorption isotherms of prepared hydrochars

Table 1 Elemental composition of CS, glucose and cellulose-derived hydrochars

\begin{tabular}{|c|c|c|c|c|c|c|}
\hline \multirow[t]{2}{*}{ Samples } & \multicolumn{4}{|c|}{ Elemental composition (wt\%) } & \multicolumn{2}{|c|}{ Atomic ratio (at.) } \\
\hline & $C$ & $\mathrm{H}$ & 0 & $\mathbf{N}$ & $\mathrm{O} / \mathrm{C}$ & $\mathrm{H} / \mathrm{C}$ \\
\hline CS-HTC & 65.26 & 4.96 & 21.50 & 1.70 & 0.247 & 0.912 \\
\hline $\mathrm{CS}-\mathrm{H}_{2} \mathrm{SO}_{4}-\mathrm{HTC}$ & 63.25 & 4.45 & 23.60 & 0.99 & 0.280 & 0.844 \\
\hline $\mathrm{CS}-\mathrm{NaOH}-\mathrm{HTC}$ & 59.65 & 4.35 & 25.19 & 0.38 & 0.317 & 0.875 \\
\hline $\mathrm{CS}-\mathrm{H}_{2} \mathrm{SO}_{4}+\mathrm{NaOH}-\mathrm{HTC}$ & 64.32 & 4.80 & 24.25 & 0.36 & 0.283 & 0.896 \\
\hline Glucose-HTC & 60.26 & 4.05 & 26.25 & ND & 0.327 & 0.807 \\
\hline Cellulose-HTC & 60.68 & 4.04 & 26.58 & ND & 0.329 & 0.799 \\
\hline
\end{tabular}

ND not detected 
Table 2 BET surface area, pore volume and pore size of CS, glucose and cellulose-derived hydrochars

\begin{tabular}{|c|c|c|c|}
\hline Samples & $S_{\mathrm{BET}}\left(\mathrm{m}^{2} / \mathrm{g}\right)$ & $\begin{array}{l}\text { Pore volume } \\
\left(\mathrm{cm}^{3} / \mathrm{g}\right)\end{array}$ & Pore size (Å) \\
\hline CS-HTC & 14.51 & 0.072 & 263.547 \\
\hline $\mathrm{CS}-\mathrm{H}_{2} \mathrm{SO}_{4}-\mathrm{HTC}$ & 14.31 & 0.065 & 190.845 \\
\hline $\mathrm{CS}-\mathrm{NaOH}-\mathrm{HTC}$ & 3.75 & 0.014 & 263.104 \\
\hline $\mathrm{CS}-\mathrm{H}_{2} \mathrm{SO}_{4}+\mathrm{NaOH}-\mathrm{HTC}$ & 7.24 & 0.034 & 255.788 \\
\hline Glucose-HTC & 15.76 & 0.018 & 44.867 \\
\hline Cellulose-HTC & 22.30 & 0.090 & 240.695 \\
\hline
\end{tabular}

hydrochars have poor porosity and low surface area. Cellulose-HTC possessed the highest BET specific surface area $\left(22.3 \mathrm{~m}^{2} / \mathrm{g}\right)$ as well as the highest pore volume $\left(0.090 \mathrm{~cm}^{3} / \mathrm{g}\right)$, which implies cellulose plays important role in hydrochar textural structure. Acid/base pretreatment could remove hemicelluloses and lignin (including acid-soluble and base-soluble lignin) that leave much looser tissue structure in plant cell wall (Isikgor and Becer 2015; Yu et al. 2019), however their derived hydrochars do not exhibit high BET surface and pore volume as expected. This phenomenon was also attributed to the fact that lignin improves microspheres, in which pores and gaps are blocked, and more crack structure is exposed (Xiao et al. 2018). As discussed in Fig. 2, NaOH could degrade lignin in CS cell wall, leading low lignin content in CS before HTC process. Thus, it is understandable that CS- $\mathrm{H}_{2} \mathrm{SO}_{4}+\mathrm{NaOH}-\mathrm{HTC}$ and CS-NaOH-HTC possess lower BET (7.24 and $3.75 \mathrm{~m}^{2} / \mathrm{g}$, respectively) than $\mathrm{CS}-\mathrm{H}_{2} \mathrm{SO}_{4}$-HTC $\left(14.31 \mathrm{~m}^{2} / \mathrm{g}\right)$. CS-NaOH-HTC behaves the lowest BET surface, it is speculated the hemicellulose residue may generate more complex products during HTC process that block the channel and the pores. Surely more researches and details are expected to help understand HTC process of biomass feedstock.

A typical CS elemental contents for $\mathrm{C}, \mathrm{H}, \mathrm{O}$ and $\mathrm{N}$ are $43.22-46.43 \%, 5.13-6.31 \%, 38.79-44.98 \%$ and $0.68-$ $1.02 \%$, respectively. BET surface area and pore volume are $1.5 \mathrm{~m}^{2} / \mathrm{g}, 0.0071 \mathrm{~cm}^{3} / \mathrm{g}$ as reported (Fu et al. 2012; Lu et al. 2021; Zhang et al. 2018a; Zhao et al. 2018). This indicates the HTC process could enhance $\mathrm{C}$ content and improve the surface exposure, which are important for dye adsorption.

The feedstock plant tissue and composition play as crucial parameters in the formation of hydrochar. But feedstock constitution effect on hydrochar structure is complex, it is thus hard to distinguish the identified action of a certain component in cell wall during the HTC process, especially the coexistence of other minor compositions (tannin and pectin, for examples) (Nizamuddin et al. 2017; Zhuang et al. 2019). Therefore, it remains to be elucidated in more detail by in situ detection technology.

FTIR measurement and powder XRD analysis were carried out to get the information of hydrochar surface functional groups and crystal structure and results are presented in Fig. 4.

As observed, the FTIR spectra of CS-HTC, CS- $\mathrm{H}_{2} \mathrm{SO}_{4^{-}}$ $\mathrm{HTC}, \mathrm{CS}-\mathrm{NaOH}-\mathrm{HTC}$ and $\mathrm{CS}-\mathrm{H}_{2} \mathrm{SO}_{4}+\mathrm{NaOH}-\mathrm{HTC}$ appear to be similar but are different in the peak intensity. The broad FTIR bands at $3300-3500 \mathrm{~cm}^{-1}$ are attributed to $\mathrm{O}-\mathrm{H}$ stretching vibrations in hydroxyl or carboxyl groups (Liu et al. 2019). The band ranges from 2850 to $2950 \mathrm{~cm}^{-1}$ is assigned to $\mathrm{C}-\mathrm{H}$ stretching modes of aromatic and aliphatic. The presence of aromatic is verified by the bands at $1620 \mathrm{~cm}^{-1}$ and $1520 \mathrm{~cm}^{-1}$, which are related to $\mathrm{C}=\mathrm{C}$ vibrations. The bands at $1710 \mathrm{~cm}^{-1}$
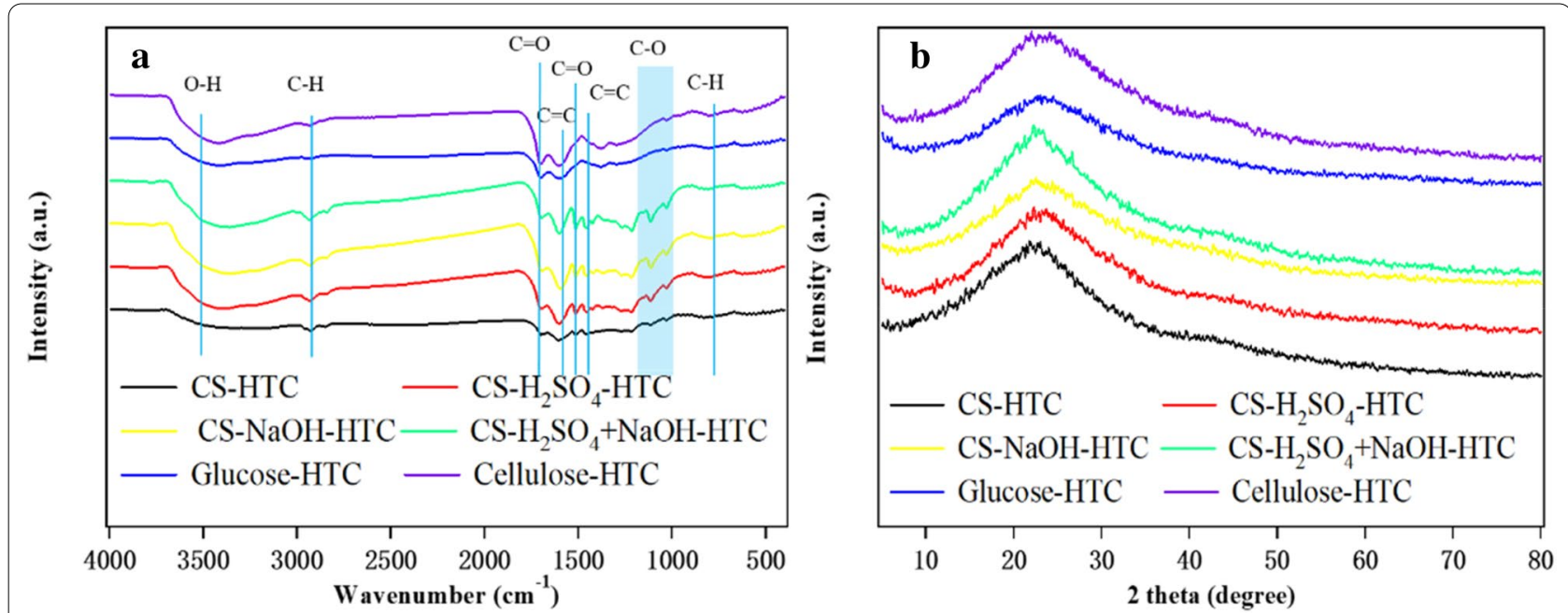

Fig. 4 FTIR spectra (a) and XRD patterns (b) of CS hydeochars, glucose and cellulose-derived hydrochars 
correspond to carboxyl vibrations $(\mathrm{C}=\mathrm{O})$. Bands at 1460 and $1440 \mathrm{~cm}^{-1}$ are due to the stretching in cyclic amide $(\mathrm{C}=\mathrm{O})$ and aromatic skeletal and ester $(\mathrm{C}=\mathrm{C})$. The bands at $1000-1250 \mathrm{~cm}^{-1}$ are assigned to $\mathrm{C}-\mathrm{O}$ stretching vibrations in hydroxyl, ester or ether and $\mathrm{O}-\mathrm{H}$ bending vibrations. The band at $870 \mathrm{~cm}^{-1}$ is ascribed to aromatic $\mathrm{C}-\mathrm{H}$ out-of-plane bending vibrations (Figueiredo et al. 1999). The intensity decreases at the bands of $1620 \mathrm{~cm}^{-1}$ for CS-HTC, which suggests a lower degree of graphitization (Buapeth et al. 2019). The higher intensity of bands at $1000-1250 \mathrm{~cm}^{-1}$ in CS- $\mathrm{H}_{2} \mathrm{SO}_{4}$ - HTC, CS$\mathrm{NaOH}-\mathrm{HTC}$ and CS- $\mathrm{H}_{2} \mathrm{SO}_{4}+\mathrm{NaOH}-\mathrm{HTC}$ means more oxygen-containing groups are formed during the HTC process because of the pretreatment with acid and base. After acid and base pretreatment, the hemicelluloses and lignin are expected to be removed and cellulose-rich materials are obtained, whereas the FTIR spectra of CS$\mathrm{H}_{2} \mathrm{SO}_{4}+\mathrm{NaOH}-\mathrm{HTC}$ and Cellulose-HTC are very different. Especially for the range from 1400 to $1800 \mathrm{~cm}^{-1}$, the CS-derived hydrochars exhibit devious peaks, indicating that their surface has multiple functional groups. According to literature (Fu et al. 2012), CS raw materials contain a number of atomic groupings and structures, such as hydroxyl, carbonyl, ether group, $\mathrm{C}-\mathrm{H}$ bond, olefinic $\mathrm{C}-\mathrm{H}$ and aromatic $\mathrm{C}=\mathrm{C}$ bond. Natural resistance of plant tissues, lower BET surface area, along with small pore volume, those functional groups are blocked. The HTC process accelerates the new chemical groups formation on the surface of CS hydrochars.

The XRD patterns of HTC hydrochar derived from CS, glucose and cellulose are shown in Fig. 4b. XRD of native CS exhibited diffraction peaks near $15-16^{\circ}, 22.5^{\circ}$, and $35^{\circ}(2 \theta)$, originating from cellulose within CS cell wall (Wang et al. 2016), while in the CS-HTC hydrochars, because of the hydrolysis reaction and further conversion of cellulose under HTC temperature, the peaks at $15-16^{\circ}$ and $35^{\circ}(2 \theta)$ have been replaced with a broad diffraction peak located at $22^{\circ}$, which corresponds to the (002) diffraction pattern of amorphous carbon (Wang et al. 2016). As summarized in reported literature (Salimi et al. 2017), the HTC crystal structure relies heavily upon HTC conditions, especially the temperature and residue time. The obtained hydrochars are all amorphous, which is intelligible under our HTC operation conditions $\left(220^{\circ} \mathrm{C}\right.$ and $6 \mathrm{~h})$.

XPS full-spectra of CS, glucose and cellulose-derived HTC samples are shown in Fig. 5. The detailed fitting is supplied in Additional file 1. Similar to the virgin CS as reported in literature (Ren et al. 2015), the $\mathrm{O}^{1 s}$ XPS spectral reveals that abundant $\mathrm{O}$-contained functional groups are on the hydrochar surface, especially the carboxy group $(-\mathrm{COOH})$. Those O-contained groups are crucial for carbon materials adsorption ability (Chen et al. 2017).

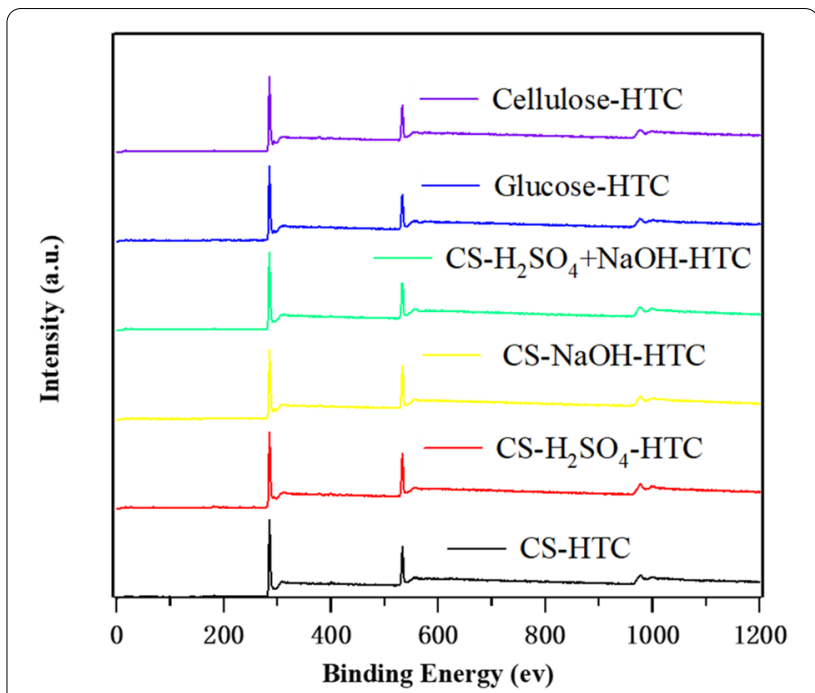

Fig. 5 XPS full-spectra of CS hydrochars, glucose and cellulose-derived hydrochars

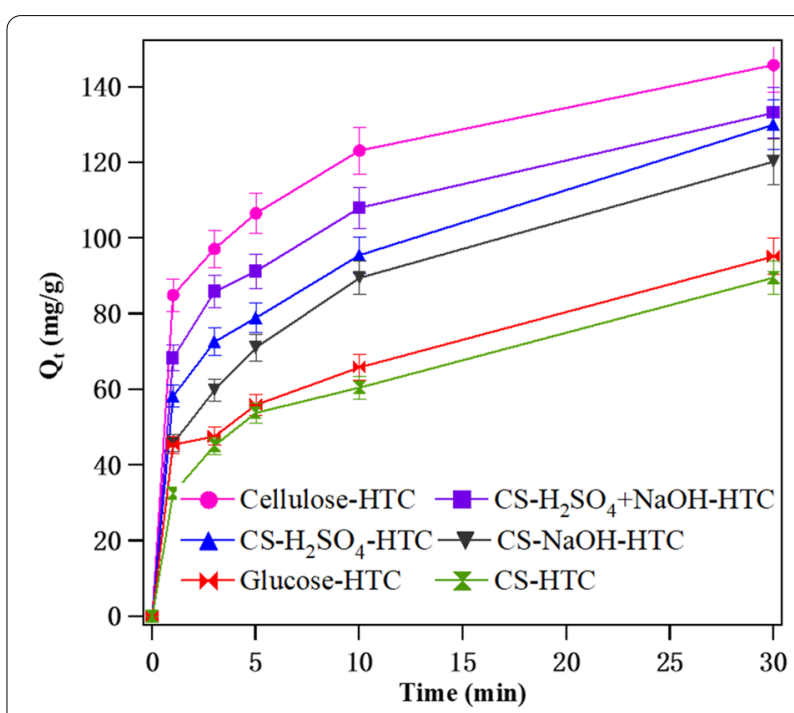

Fig. $6 \mathrm{MB}$ uptake $\left(Q_{t}\right)$ versus time of CS hydrochars, glucose and cellulose-derived hydrochars. Adsorption conditions: MB initial concentration $100 \mathrm{mg} / \mathrm{L}, \mathrm{MB}$ water solution volume $75 \mathrm{~mL}$ with a $\mathrm{pH}$ value of 7 , adsorbent dosage is $50 \mathrm{mg}, 30^{\circ} \mathrm{C}$ and $120 \mathrm{rpm}$

\section{Comparison of different hydrochar samples}

The comparison of original CS, pretreated CS with acid/ base (or both), glucose and cellulose-derived hydrochar is performed by measuring their $\mathrm{MB}$ adsorption rate; the result is shown in Fig. 6.

Cellulose-HTC presents the fastest MB adsorption rate and maximum adsorption capacity within test time. Glucose-HTC and CS-HTC show almost the same MB adsorption rate and adsorption capacity, which have the 
worst performances. Pretreatments with acid, base or both could significantly enhance CS-derived hydrochar $\mathrm{MB}$ adsorption ability. And the effects of pretreatment could be ordered in the sequence of $\mathrm{H}_{2} \mathrm{SO}_{4}+\mathrm{NaOH}$, $\mathrm{NaOH}$ and $\mathrm{H}_{2} \mathrm{SO}_{4}$.

Cellulose possesses a rod-like structure with the aid of flat bond conformation of the glucose residue. During cellulose-HTC process, the reactions of cellulose into glucose by hydrolysis and glucose into 5-hydroxymethylfurfural, levulinic acid by dehydration firstly take place (Liu et al. 2019). Experimental results show the cellulose-derived hydrochar performed better than glucose-derived hydrochar. Thus, we think the biomass raw material textural structure plays an important role on their hydrochar characterizations. Compared to glucose, cellulose is of chains that closely linked each other to form fibrous network structure because of the intermolecular hydrogen bonding (Medronho and Lindman 2015). Those fibrous network structures are beneficial to hydrochar pore volume and pore size $\left(0.090 \mathrm{~m}^{3} / \mathrm{g}\right.$, $240.695 \AA$ for Cellulose-HTC and $0.018 \mathrm{~m}^{3} / \mathrm{g}, 44.867 \AA$ for glucose-HTC as listed in Table 2) (Titirici et al. 2007), as well as to hydrochar MB adsorption capacity.

Acid/base or both pretreatments could remove hemicelluloses, lignin, and some other acid/base-soluble or $\mathrm{N}$-containing components in biomass raw material (Somsesta et al. 2020; Zhang et al. 2019). Thus, the structures of pretreated CS are similar to cellulose, which contains weakly connected plant tissues. Therefore, it is easy to understand $\mathrm{CS}-\mathrm{H}_{2} \mathrm{SO}_{4}, \mathrm{CS}-\mathrm{NaOH}-\mathrm{HTC}$ and $\mathrm{CS}-\mathrm{H}_{2} \mathrm{SO}_{4}+\mathrm{NaOH}-\mathrm{HTC}$ have higher $\mathrm{MB}$ adsorption rate and adsorption capacity than CS-HTC. However, among the three pretreated CS-derived hydrochars, CS$\mathrm{H}_{2} \mathrm{SO}_{4}+\mathrm{NaOH}-\mathrm{HTC}$ performed as the best adsorbent, which is confused. Pore volume, pore size, BET surface, along with surface functional groups are crucial for carbon materials during dye removal (Jain et al. 2016). Whereas there is no absolute advantage for the abovementioned factors in $\mathrm{CS}-\mathrm{H}_{2} \mathrm{SO}_{4}+\mathrm{NaOH}-\mathrm{HTC}$ according to Table 2. Acid treatment could remove most hemicelluloses and acid-soluble lignin in CS, base pretreatment removes most lignin, both acid and base pretreatments degrade hemicelluloses and lignin that leave celluloserich weakly connected plant tissues, while textural information does not exhibit a certain regularity, indicating the interaction among the three major components (cellulose, hemicelluloses and lignin) in CS during HTC is rather complex. Especially the CS adopted in this study has not gone through treatment with benzene extraction or alcohol extraction after harvesting. Thus, the influence of the existence of lower content compositions (tannic and pectin and ash content, for example) (Jiang et al. 2020) on the hydrochar structure and their adsorption ability are undefined. Another pheromone observed from the elemental analysis is that the $\mathrm{N}$-atom content dropped significantly in pretreated CS hydrochars (Table 1, entry 5). But according to the literature, the N-rich carbon is of high adsorption capacity (Vahdati-Khajeh et al. 2019). This result further illustrates the relationship between raw material plant tissue and their derived hydrochar structural adsorption ability is complex. Synergistic effect of the components within CS structure determines the CS-derived hydrochar MB adsorption capacity. Although some deeper understandings are undefined, this study develops a simple "acid + base" pretreatment method for the directly collected CS (without any extraction), that could improve its dye adsorption capacity. The absence of an extraction process is of great significance on the biomass raw material's direct utilization. Meanwhile, this study demonstrates that some pretreatment methods are helpful for high-valued biomass-based materials.

Surely, limitations of homogenous acid and base pretreatment of CS are obvious: the generation of polluted water with acid and base residue, along with serious corrosion to the pretreatment equipment. As an alternative way, some solid acid and base may be more suitable for the waste biomass pretreatment for the production of high-quality functional materials.

\section{Effect of initial MB concentration, temperature, $\mathrm{pH}$ and reusability}

To gain further insight into the CS hydrochar MB dye adsorption capacity, taking CS- $\mathrm{H}_{2} \mathrm{SO}_{4}+\mathrm{NaOH}-\mathrm{HTC}$ as the adsorbent, the parameters like initial MB concentration, temperature, $\mathrm{pH}$ value and reusability on adsorption were studied and results are shown in Fig. 7.

$\mathrm{MB}$ concentrations were investigated to evaluate the adsorption of $\mathrm{MB}$ dyes onto $\mathrm{CS}-\mathrm{H}_{2} \mathrm{SO}_{4}+\mathrm{NaOH}-\mathrm{HTC}$, shown in Fig. 7a. The adsorption reached equilibrium at low $\mathrm{MB}$ concentrations of 50 and $100 \mathrm{mg} / \mathrm{L}$ within $10 \mathrm{~min}$ and subsequently remained constant. Higher $\mathrm{MB}$ concentrations required a longer time $(25-120 \mathrm{~min})$ to reach equilibrium. Eventually, the needed contact time for $\mathrm{MB}$ initial concentration of $300 \mathrm{mg} / \mathrm{L}$ reached up to $120 \mathrm{~min}$ to reach equilibrium under fixed adsorbent dosage. This observation was in agreement with the results reported by some other research groups (Islam et al. 2015; Li et al. 2011) and can be explained by the fact that molecule adsorptive competition toward the active adsorption sites of CS- $\mathrm{H}_{2} \mathrm{SO}_{4}+\mathrm{NaOH}-\mathrm{HTC}$ surface is intensified because of the increasing initial $\mathrm{MB}$, which leads to an enhanced equilibrium time (Chen et al. 2010). The maximum MB adsorption capacity of MB onto CS$\mathrm{H}_{2} \mathrm{SO}_{4}+\mathrm{NaOH}-\mathrm{HTC}$ is $198.0 \pm 9.8 \mathrm{mg} / \mathrm{g}$, which is higher than $\mathrm{CS}-\mathrm{H}_{2} \mathrm{SO}_{4}, \mathrm{CS}-\mathrm{NaOH}$ and $\mathrm{CS}-\mathrm{H}_{2} \mathrm{SO}_{4}+\mathrm{NaOH}$ (maximum $\mathrm{MB}$ adsorption capacity are $120.1 \pm 5.6$, 

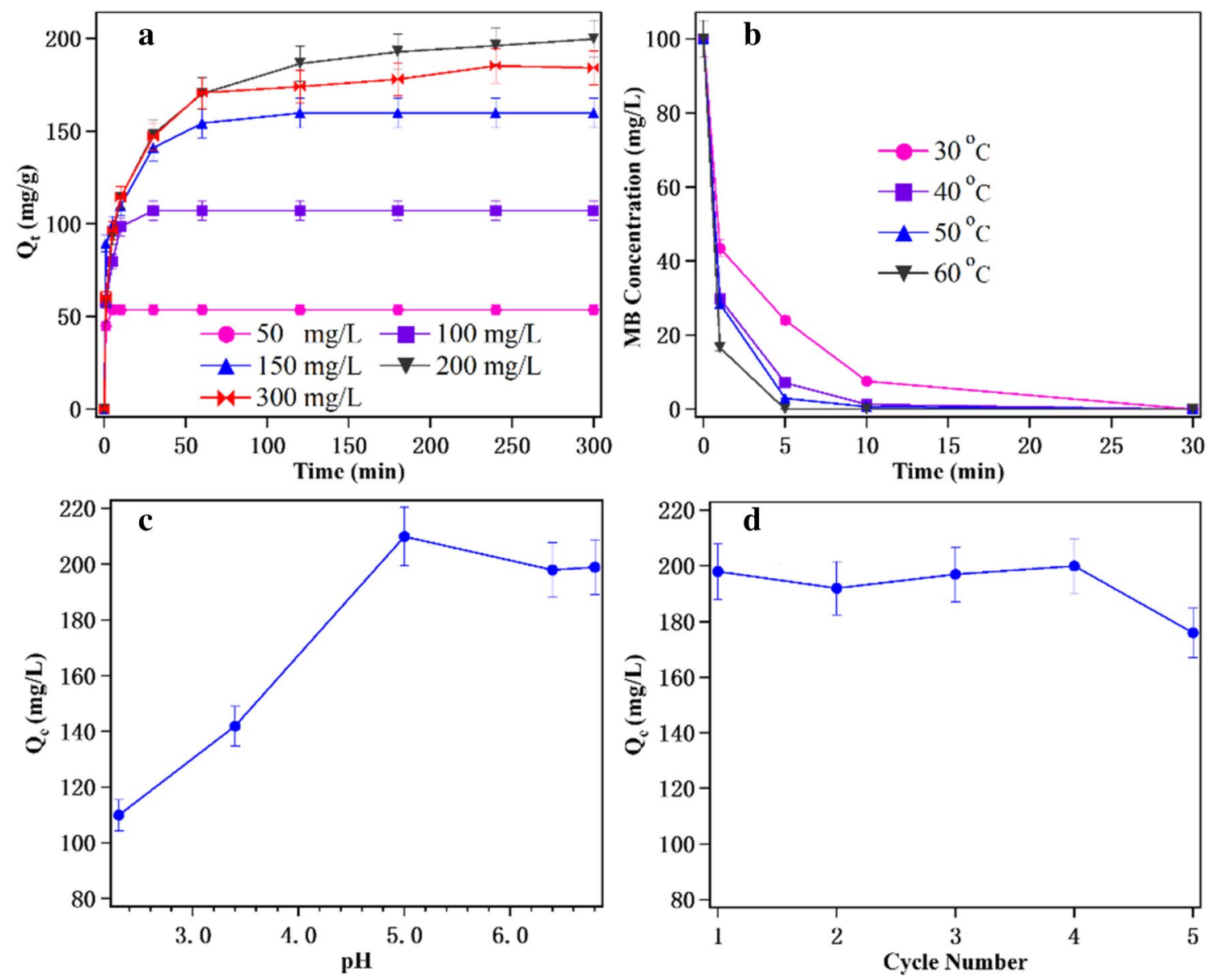

Fig. 7 Effect of initial concentration (a), temperature (b), solution $\mathrm{pH}(\mathbf{b})$ and reusability on remove of $\mathrm{MB}$ onto $\mathrm{CS}-\mathrm{H}_{2} \mathrm{SO} 4+\mathrm{NaOH}-\mathrm{HTC}$. Adsorption conditions: a MB water solution volume is $75 \mathrm{~mL}$ with a $\mathrm{pH}$ value of 7 , adsorbent dosage is $70 \mathrm{mg}, 30^{\circ} \mathrm{C}$; $\mathbf{b}$ MB water solution volume $75 \mathrm{~mL}$ with a concentration of $100 \mathrm{mg} / \mathrm{L}$ with a pH value of 7 , adsorbent dosage is $70 \mathrm{mg} ; \mathbf{c}$ MB water solution volume $75 \mathrm{~mL}$ with a concentration of $300 \mathrm{mg} / \mathrm{L}$, adsorbent dosage is $70 \mathrm{mg}, 30^{\circ} \mathrm{C}$ and $120 \mathrm{~min}$; $\mathbf{d ~ M B}$ water solution volume $75 \mathrm{~mL}$ with a concentration of $300 \mathrm{mg} / \mathrm{L}$, adsorbent dosage is $70 \mathrm{mg}$, $30^{\circ} \mathrm{C}$ and $120 \mathrm{~min}$. The shake speed for each batch experiment is $120 \mathrm{rpm}$

$123.4 \pm 4.3,126.5 \pm 7.2$ and $135.7 \pm 6.2 \mathrm{mg} / \mathrm{g}$, respectively). It is thought the HTC process make more C content and expose more surface as discussed above. The $\mathrm{MB}$ removal rate $R$ (\%) for $\mathrm{CS}-\mathrm{H}_{2} \mathrm{SO}_{4}+\mathrm{NaOH}-\mathrm{HTC}$ is calculated by the equation $R(\%)=\frac{100 Q_{t} W}{V * C_{0}}$, the results reveal that for initial MB concentration of 50, 100, 150, 200 and $300 \mathrm{mg} / \mathrm{L}$, the MB removal rate are $100 \%, 100 \%, 99.4 \%$, 93.2\% and 57.3\%, respectively, which exhibits excellent adsorption capacity under lower MB concentration.

The effect of temperature on MB removal was also studied. Result reveals the adsorption rate of $\mathrm{MB}$ onto CS- $\mathrm{H}_{2} \mathrm{SO}_{4}+\mathrm{NaOH}-\mathrm{HTC}$ is proportional to temperature. As known, the whole adsorption process of aqueous molecules onto adsorbent includes two steps: (1) MB molecules transfer from solution to the adsorbent near surface; and (2) the adsorption from near surface to the adsorbent surface (Gadekar and Ahammed 2019). The thermodynamic analyses have been done and the details can be seen in Additional file 1 . The fitted $\Delta H=23.76 \mathrm{~kJ} /$ mol, which is below $40 \mathrm{~kJ} / \mathrm{mol}$, implying that the adsorption of $\mathrm{MB}$ by CS- $\mathrm{H}_{2} \mathrm{SO}_{4}+\mathrm{NaOH}-\mathrm{HTC}$ is a physisorption process (Neolaka et al. 2018; Shu et al. 2018).

$\mathrm{pH}$ value of the solution can affect $\mathrm{MB}$ adsorption onto CS- $\mathrm{H}_{2} \mathrm{SO}_{4}+\mathrm{NaOH}-\mathrm{HTC}$ by adjusting surface charges. The capacity of MB adsorption in the presence of different $\mathrm{pH}$ values ranging from 2.0 to 7.0 was detected as shown in Fig. 7c. Results indicate that the $\mathrm{pH}$ value of solution exerted a significant influence on the $\mathrm{MB}$ adsorption onto CS- $\mathrm{H}_{2} \mathrm{SO}_{4}+\mathrm{NaOH}-\mathrm{HTC}$. At lower $\mathrm{pH}$, cationic $\mathrm{MB}$ resists to combine with acidified adsorbent surface because of the electrostatic repulsive force that weakens mass transfer and leads to a reduction in $\mathrm{MB}$ removal percentages (Ghaedi et al. 2016; Zhang et al. 
2019). The maximum $\mathrm{MB}$ adsorption was achieved at a $\mathrm{pH}$ value of 7.0, which can be explained by the fact that the absented positive charge on $\mathrm{H}_{2} \mathrm{SO}_{4}+\mathrm{NaOH}-\mathrm{HTC}$ surface can enhance $\mathrm{MB}$ mass transfer and adsorption. An alkali environment was not investigated in this study because there is an agreement that the competitive $\mathrm{MB}$ adsorption onto reactive sites with abundant $\mathrm{OH}^{-}$in solution will lead to the MB adsorption reduced (Ghaedi et al. 2016). In fact, aniline and malachite green oxalate salt were also tested to evaluate their adsorption capacity onto $\mathrm{H}_{2} \mathrm{SO}_{4}+\mathrm{NaOH}-\mathrm{HTC}$ at the same conditions (adsorbent dosage is $70 \mathrm{mg}, 30^{\circ} \mathrm{C}$ and $120 \mathrm{~min}$ ). The maximum adsorption are $19.2 \pm 2.0 \mathrm{mg} / \mathrm{L}$ and $319 \pm 13.2 \mathrm{mg} / \mathrm{L}$ for aniline and malachite green oxalate salt, respectively. The low aniline adsorption ability is due to its low solubility in water. And malachite green oxalate salt is cationic that can readily adsorb onto $\mathrm{H}_{2} \mathrm{SO}_{4}+\mathrm{NaOH}-\mathrm{HTC}$ surface under neutral solution as well as $\mathrm{MB}$.

Recyclability of $\mathrm{H}_{2} \mathrm{SO}_{4}+\mathrm{NaOH}-\mathrm{HTC}$ was investigated and shown in Fig. 7d. The regeneration of adsorbent was realized by washing with $\mathrm{HCl}(2 \mathrm{M})$ solution, ethanol and DI water to remove impurity and adsorbed dye completely (Vahdati-Khajeh et al. 2019). Finally, the regenerated adsorbent was dried at $50{ }^{\circ} \mathrm{C}$ and used in the next run. The maximum $\mathrm{MB}$ adsorption remained at $176 \pm 8.6 \mathrm{mg} / \mathrm{L}$ over four adsorption-desorption cycles with a slightly reducing of $198 \pm 9.8 \mathrm{mg} / \mathrm{L}$ at the first adsorption test, suggesting that $\mathrm{HCl}$ and ethanol can be used as good desorption/regeneration agents and the $\mathrm{H}_{2} \mathrm{SO}_{4}+\mathrm{NaOH}-\mathrm{HTC}$ possesses high stability.

\section{Conclusion}

Conclusively, we investigated the influence of simple acid/base or both pretreatment on agricultural residue biomass cotton stalk (CS) derived hydrothermal carbonization. The chemical structures and properties of the prepared hydrochars are compared by their methylene blue $(\mathrm{MB})$ dye adsorption capacity. Material characterization and $\mathrm{MB}$ removal test reveal that selective removal of components within CS with the aid of acid/base (or both) is of benefits to the preparation of high-quality carbonaceous materials by the HTC method. During the $\mathrm{MB}$ adsorption onto $\mathrm{CS}-\mathrm{H}_{2} \mathrm{SO}_{4}+\mathrm{NaOH}-\mathrm{HTC}$, initial $\mathrm{MB}$ concentration evaluation reveal that high $\mathrm{MB}$ initial concentrations require longer time to reach equilibrium for the cases with fixed adsorbent dosage. Temperature investigation demonstrates the adsorption process is a physisorption process. $\mathrm{pH}$ value of solution affects the hydrochar surface electrical charge as well as $\mathrm{MB}$ removal ability. Finally, the recyclability test indicates the CS-derived hydrochar could be easily regenerated by simple washing with $\mathrm{HCl}$ and ethanol. It is noted that the CS used in this study was without any extraction after harvesting that simplifies the process and of great significance on the direct utilization of waste biomass.

\section{Supplementary Information}

The online version contains supplementary material available at https://doi. org/10.1186/s40643-021-00364-8.

Additional file 1. Supporting information.

\section{Abbreviations}

CS: Cotton stalk; HTC: Hydrothermal carbonization; FTIR: Fourier transform infrared; XPS: X-ray photoelectron spectroscopy; XRD: X-ray diffraction; MB: Methylene blue; $\mathrm{H}_{2} \mathrm{SO}_{4}$ : Sulfuric acid; $\mathrm{NaOH}$ : Sodium hydroxide; $\mathrm{KOH}$ : Potassium hydroxide; $\mathrm{HCl}$ : Hydrochloric acid.

\section{Acknowledgements}

The authors greatly thank Professor Yu Chen at China University of PetroleumBeijing for useful discussion.

\section{Authors' contributions}

LZ designed the study. JT and GX performed the experiment and wrote a part of the manuscript. XD and XG wrote a part of the manuscript and polished the manuscript. All authors read and approved the final manuscript.

\section{Funding}

This work was supported by the Scientific Research Program of Universities in Xinjiang Uygur Autonomous Region (Grant No. XJEDU2019Y068), Research Foundation of China University of Petroleum-Beijing at Karamay (Grant No. YJ2018B02006).

\section{Availability of data and materials}

All data generated or analyzed during this study are included in this article.

\section{Consent for publication}

Not applicable.

\section{Competing interests}

The authors declare that they have no competing interests.

\section{Author details}

${ }^{1}$ State Key Laboratory of Heavy Oil Processing, College of Engineering, China University of Petroleum-Beijing at Karamay, Karamay 834000, People's Republic of China. ${ }^{2}$ Shenzhen College of International Education, Shenzhen 518048, People's Republic of China. ${ }^{3}$ State Key Laboratory of Heavy Oil Processing, China University of Petroleum, Beijing 102249, People's Republic of China.

Received: 30 November 2020 Accepted: 25 January 2021

Published online: 30 January 2021

\section{References}

Adebisi GA, Chowdhury ZZ, Abd Hamid SB, Ali E (2016) Hydrothermally treated banana empty fruit bunch fiber activated carbon for $\mathrm{Pb}(\mathrm{II})$ and Zn(II) removal. BioResources 11(4):9686-9709

Boostani HR, Najafi-Ghiri M, Mirsoleimani A (2019) The effect of biochars application on reducing the toxic effects of nickel and growth indices of spinach (Spinacia oleracea L.) in a calcareous soil. Environ Sci Pollut Res 26(2):1751-1760. https://doi.org/10.1007/s11356-018-3760-x

Bridgwater AV (2012) Review of fast pyrolysis of biomass and product upgrading. Biomass Bioenergy 38:68-94. https://doi.org/10.1016/j.biomb ioe.2011.01.048

Buapeth P, Watcharin W, Dechtrirat D, Chuenchom L (2019) Carbon adsorbents from sugarcane bagasse prepared through hydrothermal carbonization for adsorption of methylene blue: effect of heat treatment on adsorption efficiency. IOP Conf Ser Mater Sci Eng 515:012003. https://doi. org/10.1088/1757-899x/515/1/012003 
Chen S, Zhang J, Zhang C, Yue Q, LiY, Li C (2010) Equilibrium and kinetic studies of methyl orange and methyl violet adsorption on activated carbon derived from Phragmites australis. Desalination 252(1):149-156. https:// doi.org/10.1016/j.desal.2009.10.010

Chen Y, Zhang X, Chen W, Yang H, Chen H (2017) The structure evolution of biochar from biomass pyrolysis and its correlation with gas pollutant adsorption performance. Bioresour Technol 246:101-109. https://doi. org/10.1016/j.biortech.2017.08.138

Chu S, Subrahmanyam AV, Huber GW (2013) The pyrolysis chemistry of a $\beta-\mathrm{O}-4$ type oligomeric lignin model compound. Green Chem 15(1):125-136. https://doi.org/10.1039/C2GC36332A

Figueiredo JL, Pereira MFR, Freitas MMA, Órfão JJM (1999) Modification of the surface chemistry of activated carbons. Carbon 37(9):1379-1389. https:// doi.org/10.1016/S0008-6223(98)00333-9

Foong SY, Liew RK, Yang Y, Cheng YW, Yek PNY, Wan Mahari WA, Lee XY, Han CS, Vo D-VN, Van Le Q, Aghbashlo M, Tabatabaei M, Sonne C, Peng W, Lam SS (2020) Valorization of biomass waste to engineered activated biochar by microwave pyrolysis: progress, challenges, and future directions. Chem Eng J 389:124401. https://doi.org/10.1016/j.cej.2020.124401

Fu P, Hu S, Xiang J, Sun L, Su S, An S (2012) Study on the gas evolution and char structural change during pyrolysis of cotton stalk. J Anal Appl Pyrolysis 97:130-136. https://doi.org/10.1016/j.jaap.2012.05.012

Gadekar MR, Ahammed MM (2019) Modelling dye removal by adsorption onto water treatment residuals using combined response surface methodology-artificial neural network approach. J Environ Manag 231:241-248. https://doi.org/10.1016/j.jenvman.2018.10.017

Ghaedi M, Rahimi MR, Ghaedi AM, Tyagi I, Agarwal S, Gupta VK (2016) Application of least squares support vector regression and linear multiple regression for modeling removal of methyl orange onto tin oxide nanoparticles loaded on activated carbon and activated carbon prepared from Pistacia atlantica wood. J Colloid Interface Sci 461:425-434. https://doi. org/10.1016/j.jcis.2015.09.024

Guo F, Jia X, Liang S, Zhou N, Chen P, Ruan R (2020) Development of biocharbased nanocatalysts for tar cracking/reforming during biomass pyrolysis and gasification. Bioresour Technol 298:122263. https://doi.org/10.1016/j. biortech.2019.122263

Hamawand I, Sandell G, Pittaway P, Chakrabarty S, Yusaf T, Chen G, Seneweera S, Al-Lwayzy S, Bennett J, Hopf J (2016) Bioenergy from cotton industry wastes: a review and potential. Renew Sustain Energy Rev 66:435-448. https://doi.org/10.1016/j.rser.2016.08.033

Hussain M, Imran M, Abbas G, Shahid M, Iqbal M, Naeem MA, Murtaza B, Amjad M, Shah NS, UI Haq Khan Z, Ul Islam A (2020) A new biochar from cotton stalks for $\mathrm{As}(\mathrm{V})$ removal from aqueous solutions: its improvement with $\mathrm{H}_{3} \mathrm{PO}_{4}$ and $\mathrm{KOH}$. Environ Geochem Health 42(8):2519-2534. https:// doi.org/10.1007/s10653-019-00431-2

Isikgor FH, Becer CR (2015) Lignocellulosic biomass: a sustainable platform for the production of bio-based chemicals and polymers. Polymer Chem 6(25):4497-4559. https://doi.org/10.1039/C5PY00263J

Islam MA, Tan IA, Benhouria A, Asif M, Hameed BH (2015) Mesoporous and adsorptive properties of palm date seed activated carbon prepared via sequential hydrothermal carbonization and sodium hydroxide activation. Chem Eng J 270:187-195. https://doi.org/10.1016/j.cej.2015.01.058

Jain A, Balasubramanian R, Srinivasan MP (2016) Hydrothermal conversion of biomass waste to activated carbon with high porosity: a review. Chem Eng J. 283:789-805. https://doi.org/10.1016/i.cej.2015.08.014

Jiang Y, Xu Y, Li F, Li D, Huang Q (2020) Pectin extracted from persimmon peel: a physicochemical characterization and emulsifying properties evaluation. Food Hydrocoll 101:105561. https://doi.org/10.1016/j.foodh yd.2019.105561

Khan TA, Saud AS, Jamari SS, Rahim MHA, Park J-W, Kim H-J (2019) Hydrothermal carbonization of lignocellulosic biomass for carbon rich material preparation: a review. Biomass Bioenergy 130:105384. https://doi. org/10.1016/j.biombioe.2019.105384

Laird DA, Brown RC, Amonette JE, Lehmann J (2009) Review of the pyrolysis platform for coproducing bio-oil and biochar. Biofuels Bioprod Biorefin 3(5):547-562. https://doi.org/10.1002/bbb.169

Li W-H, Yue Q-Y, Gao B-Y, Ma Z-H, Li Y-J, Zhao H-X (2011) Preparation and utilization of sludge-based activated carbon for the adsorption of dyes from aqueous solutions. Chem Eng J 171(1):320-327. https://doi.org/10.1016/j. cej.2011.04.012
Li M, Yang X, Lu T, Zhou L (2020a) Selective hydrolysis of hemicellulose component of wheat straw in high-pressure $\mathrm{CO}_{2}$ and water with low concentration of acetic acid. J Chem Technol Biotechnol 95(8):2237-2242. https:// doi.org/10.1002/jctb.6411

Li Y, Zhu Q, Ding P, You S, Zhang Q, Jiang H (2020b) Effects of FeO and NiO nanoparticles on hydrogen production from cotton stalk hydrolysate using Klebsiella sp. WL1316: evaluation of size and concentration of the nanoparticles. Int J Hydrog Energy 45(11):6243-6253. https://doi. org/10.1016/j.jijydene.2020.01.012

Liu W-J, Jiang H, Yu H-Q (2015) Development of biochar-based functional materials: toward a sustainable platform carbon material. Chem Rev 115(22):12251-12285. https://doi.org/10.1021/acs.chemrev.5b00195

Liu J, Zhang S, JinShuang CE, Sheng K, Zhang X (2019) Effect of swelling pretreatment on properties of cellulose-based hydrochar. ACS Sustain Chem Eng 7(12):10821-10829. https://doi.org/10.1021/acssuschem eng. 9 b01640

Lu C, Zhang X, Gao Y, Lin Y, Xu J, Zhu C, Zhu Y (2021) Parametric study of catalytic co-gasification of cotton stalk and aqueous phase from wheat straw using hydrothermal carbonation. Energy 216:1 19266. https://doi. org/10.1016/j.energy.2020.119266

Machado G, Leon S, Santos F, Lourega R, Dullius J, Mollmann ME, Eichler PJNR (2016) Literature review on furfural production from lignocellulosic biomass. Nat Resour 7(3):115-129. https://doi.org/10.4236/nr.2016.73012

Malik K, Salama E-S, Kim TH, Li X (2020) Enhanced ethanol production by Saccharomyces cerevisiae fermentation post acidic and alkali chemical pretreatments of cotton stalk lignocellulose. Int Biodeterior Biodegrad 147:104869. https://doi.org/10.1016/j.ibiod.2019.104869

Medronho B, Lindman B (2015) Brief overview on cellulose dissolution/ regeneration interactions and mechanisms. Adv Colloid Interface Sci 222:502-508. https://doi.org/10.1016/j.cis.2014.05.004

Nizamuddin S, Baloch HA, Griffin GJ, Mubarak NM, Bhutto AW, Abro R, Mazari SA, Ali BS (2017) An overview of effect of process parameters on hydrothermal carbonization of biomass. Renew Sustain Energy Rev. 73:12891299. https://doi.org/10.1016/j.rser.2016.12.122

Neolaka YA, Kalla EB, Malelak GA, Rukman NK, Supriyanto G, Puspaningsih NNTJRJOC (2018) Adsorption of methylene blue using acid activated green color natural zeolite from Ende-Flores, Indonesia. Rasāyan J Chem 11(2):494-504

Nizamuddin S, Baloch HA, Griffin GJ, Mubarak NM, Bhutto AW, Abro R, Mazari SA, Ali BS (2017) An overview of effect of process parameters on hydrothermal carbonization of biomass. Renew Sustain Energy Rev 73:12891299. https://doi.org/10.1016/..rser.2016.12.122

Ren Z, Xu X, Gao B, Yue Q, Song W (2015) Integration of adsorption and direct bio-reduction of perchlorate on surface of cotton stalk based resin. J Colloid Interface Sci 459:127-135. https://doi.org/10.1016/j.jcis.2015.08.016

Román S, Nabais JMV, Laginhas C, Ledesma B, González JF (2012) Hydrothermal carbonization as an effective way of densifying the energy content of biomass. Fuel Process Technol 103:78-83. https://doi.org/10.1016/j.fupro c.2011.11.009

Rusanen A, Lappalainen K, Kärkkäinen J, Tuuttila T, Mikola M, Lassi U (2019) Selective hemicellulose hydrolysis of Scots pine sawdust. Biomass Convers Biorefin 9(2):283-291. https://doi.org/10.1007/s13399-018-0357-z

Salimi M, Balou S, Kohansal K, Babaei K, Tavasoli A, Andache M (2017) Optimizing the preparation of meso- and microporous canola stalk-derived hydrothermal carbon via response surface methodology for methylene blue removal. Energy Fuels 31(11):12327-12338. https://doi.org/10.1021/ acs.energyfuels. $7 \mathrm{~b} 02440$

Sevilla M, Fuertes AB (2009) The production of carbon materials by hydrothermal carbonization of cellulose. Carbon 47(9):2281-2289. https://doi. org/10.1016/j.carbon.2009.04.026

Shu J, Liu R, Wu H, Liu Z, Sun X, Tao C (2018) Adsorption of methylene blue on modified electrolytic manganese residue: kinetics, isotherm, thermodynamics and mechanism analysis. J Taiwan Inst Chem Eng 82:351-359. https://doi.org/10.1016/j.jtice.2017.11.020

Smith AM, Singh S, Ross AB (2016) Fate of inorganic material during hydrothermal carbonisation of biomass: influence of feedstock on combustion behaviour of hydrochar. Fuel 169:135-145. https://doi.org/10.1016/j. fuel.2015.12.006

Somsesta N, Piyamawadee C, Sricharoenchaikul V, Aht-Ong D (2020) Adsorption isotherms and kinetics for the removal of cationic dye by 
cellulose-based adsorbent biocomposite films. Korean J Chem Eng 37(11):1999-2010. https://doi.org/10.1007/s11814-020-0602-6

Song X, Zhang S, Wu Y, Cao Z (2020) Investigation on the properties of the biobriquette fuel prepared from hydrothermal pretreated cotton stalk and wood sawdust. Renew Energy 151:184-191. https://doi.org/10.1016/j. renene.2019.11.003

Sun C, Zheng L, Xu W, Dushkin AV, Su W (2020) Mechanochemical cleavage of lignin models and lignin via oxidation and a subsequent base-catalyzed strategy. Green Chem 22(11):3489-3494. https://doi.org/10.1039/D0GC0 0372G

Titirici MM, Thomas A, Yu S-H, Müller J-O, Antonietti M (2007) A direct synthesis of mesoporous carbons with bicontinuous pore morphology from crude plant material by hydrothermal carbonization. Chem Mater 19(17):42054212. https://doi.org/10.1021/cm0707408

Tu R, Sun Y, Wu Y, Fan X, Wang J, Shen X, He Z, Jiang E, Xu XJBT (2019) Effect of surfactant on hydrothermal carbonization of coconut shell. Bioresour Technol 284:214-221

Ukanwa KS, Patchigolla K, Sakrabani R, Anthony E, Mandavgane S (2019) A review of chemicals to produce activated carbon from agricultural waste biomass. Sustainability 11(22):6204. https://doi.org/10.3390/su11226204

Vahdati-Khajeh S, Zirak M, Tejrag RZ, Fathi A, Lamei K, Eftekhari-Sis B (2019) Biocompatible magnetic $\mathrm{N}$-rich activated carbon from egg white biomass and sucrose: preparation, characterization and investigation of dye adsorption capacity from aqueous solution. Surf Interfaces 15:157-165. https://doi.org/10.1016/j.surfin.2019.03.003

Wang M, Zhou D, Wang Y, Wei S, Yang W, Kuang M, Ma L, Fang D, Xu S, Du S-K (2016) Bioethanol production from cotton stalk: a comparative study of various pretreatments. Fuel 184:527-532. https://doi.org/10.1016/j. fuel.2016.07.061

Wang Z, Shu X, Zhu H, Xie L, Cheng S, Zhang Y (2020) Characteristics of biochars prepared by co-pyrolysis of sewage sludge and cotton stalk intended for use as soil amendments. Environ Technol 41(11):1347-1357. https://doi.org/10.1080/09593330.2018.1534891

Xiao K, Liu H, Li Y, Yi L, Zhang X, Hu H, Yao H (2018) Correlations between hydrochar properties and chemical constitution of orange peel waste during hydrothermal carbonization. Bioresour Technol 265:432-436. https://doi.org/10.1016/j.biortech.2018.06.014

Xie Y, Zeng K, Flamant G, Yang H, Liu N, He X, Yang X, Nzihou A, Chen H (2019) Solar pyrolysis of cotton stalk in molten salt for bio-fuel production. Energy 179:1124-1132. https://doi.org/10.1016/j.energy.2019.05.055

Xu X, Tu R, Sun Y, Wu Y, Jiang E, Zhen J (2019) The influence of combined pretreatment with surfactant/ultrasonic and hydrothermal carbonization on fuel properties, pyrolysis and combustion behavior of corn stalk. Bioresour Technol 271:427-438. https://doi.org/10.1016/j.biortech.2018.09.066

Yang D-P, Li Z, Liu M, Zhang X, Chen Y, Xue H, Ye E, Luque R (2019a) Biomassderived carbonaceous materials: recent progress in synthetic approaches, advantages, and applications. ACS Sustain Chem Eng 7(5):4564-4585. https://doi.org/10.1021/acssuschemeng.8b06030

Yang Z, Xing R, Zhou W (2019b) Adsorption of ciprofloxacin and $\mathrm{Cu}^{2+}$ onto biochars in the presence of dissolved organic matter derived from animal manure. Environ Sci Pollut Res 26(14):14382-14392. https://doi. org/10.1007/s11356-019-04760-8

Yu K, Wang J, Song K, Wang X, Liang C, Dou Y (2019) Hydrothermal synthesis of cellulose-derived carbon nanospheres from corn straw as anode materials for lithium ion batteries. Nanomaterials 9(1):93

Zhang H, Ning Z, Khalid H, Zhang R, Liu G, Chen C (2018a) Enhancement of methane production from cotton stalk using different pretreatment techniques. Sci Rep 8(1):3463. https://doi.org/10.1038/s41598-018-21413-x

Zhang L, Zheng W, Wang Z, Ma Y, Jiang L, Wang T (2018b) Efficient degradation of lignin in raw wood via pretreatment with heteropoly acids in $\gamma$-valerolactone/water. Bioresour Technol 261:70-75. https://doi. org/10.1016/j.biortech.2018.03.141

Zhang X, Ge Y, Zhu G, Tang J, Xing X, Li N (2019) Effect of acid and hydrothermal treatments on the multilayer adsorption of $\mathrm{Cr}(\mathrm{VI})$ and dyes on biomass-derived nano/mesoporous carbon. J Mater Res 34(17):30203029. https://doi.org/10.1557/jmr.2019.155

Zhang H, Zhang J, Xie J, Qin Y (2020a) Effects of $\mathrm{NaOH}$-catalyzed organosolv pretreatment and surfactant on the sugar production from sugarcane bagasse. Bioresour Technol 312:123601. https://doi.org/10.1016/j.biort ech.2020.123601

Zhang L, Xing B, Deng B, Wang T, Ming H (2020b) Oxidation of petroleumbased byproducts diformyltricyclodecanes (DFTD) with $\mathrm{O}_{2}$ under catalyst-free and ultra-low temperature. Chin J Chem Eng 28(1):266-270. https://doi.org/10.1016/j.cjche.2019.04.012

Zhao Y, Ren Q, Na Y (2018) Promotion of cotton stalk on bioavailability of phosphorus in municipal sewage sludge incineration ash. Fuel 214:351-355. https://doi.org/10.1016/j.fuel.2017.11.044

Zhou B, Ma G, Zhao X, Zhao X (2019) Preparation and properties of biogeopolymer composites with waste cotton stalk materials. J Clean Prod 245:118842. https://doi.org/10.1016/j.jclepro.2019.118842

Zhuang X, Zhan H, Song Y, He C, Huang Y, Yin X, Wu C (2019) Insights into the evolution of chemical structures in lignocellulose and non-lignocellulose biowastes during hydrothermal carbonization (HTC). Fuel 236:960-974. https://doi.org/10.1016/j.fuel.2018.09.019

\section{Publisher's Note}

Springer Nature remains neutral with regard to jurisdictional claims in published maps and institutional affiliations.

\section{Submit your manuscript to a SpringerOpen ${ }^{\circ}$ journal and benefit from:}

- Convenient online submission

- Rigorous peer review

- Open access: articles freely available online

- High visibility within the field

- Retaining the copyright to your article

Submit your next manuscript at $\boldsymbol{\nabla}$ springeropen.com 